\title{
Excavators and dirt: assessing the quarantine risk posed by nematodes and seeds
}

\author{
L.T. Aalders ${ }^{1}$, T.K. James ${ }^{1}$ and M.R. McNeill ${ }^{2}$ \\ ${ }^{1}$ AgResearch Ltd, Ruakura Research Centre, Private Bag 3123, Hamilton, New Zealand \\ ${ }^{2}$ AgResearch, Private Bag 4749, Christchurch 8140, New Zealand \\ Corresponding author: mark.mcneill@agresearch.co.nz
}

\begin{abstract}
A used stump grinding excavator was imported from Bathurst, Australia, into New Zealand via the Ports of Auckland. The excavator was subject to water blasting to remove soil contamination. Prior to cleaning, soil was taken from one of the tracks (26 g) and grinding head (a subsample of $2140 \mathrm{~g}$ ), to determine nematode and seed numbers, and diversity. The predominant nematode group for both samples was bacterial feeders, although-plant associated nematodes were present, with the track sample having a more diverse nematode community and greater number of nematodes (85/g soil) than the grinding head (4/g soil). There were 56 seeds of nine different species recovered, with just two species, Eleusine tristachya (Poaceae) and Juncus bufonius (Juncaceae), accounting for $84 \%$ of the seed found. Soil from the track was found to contain $1.2 \mathrm{seeds} / \mathrm{g}$ while that from the head contained $0.01 \mathrm{seeds} / \mathrm{g}$ of soil. There were five broadleaf species but only seven seeds in total. One of the broadleaf species, Monopsis lutea var. depressa, was new to New Zealand, and one of the grasses, Eragrostis mexicana, had only been found once before - more than 100 years ago. All the other species, except one, are widespread throughout New Zealand.
\end{abstract}

